\title{
Assessment of semen characteristics and in vivo conception rate of preserved buffalo bull semen extended in tris enhanced with Diospyros kaki
}

\author{
Reda Ibrahim El-Sheshtawy and Walid Said El-Nattat ${ }^{*}$ (1)
}

\begin{abstract}
Background: The freeze-thaw process results in structural and functional damages caused by over accumulation of reactive oxygen species (ROS). Addition of exogenous antioxidants to semen extender is of a great importance to overcome the oxidative damage during the freezing process. The present study aimed to clarify the impact of Diospyros kaki on preserved buffalo semen quality. Tris extender enhanced with kaki juice (KEE) at concentrations $0 \%$ (control) and $1-10 \%(\mathrm{~V} / \mathrm{V})$. A twenty percent of freshly prepared egg yolk was added to the KEE extender (KEEY), then all tubes were centrifuged to eliminate any debris. Semen was added to the supernatants in other tubes. Semen was evaluated and the conception rate was implemented.

Results: Sperm forward motility was significantly $(P<0.0001)$ kept high after 5 days of chilling for the concentrations 3 , 4 , and $5 \%$ with respect to the control and kept high $(P<0.01)$ at the other concentrations till the 4th day of chilling. Addition of KEE had significantly $(P<0.03)$ ameliorated post freezing sperm motility with all the concentrations of the extender except the concentration (10\%). The highest spermatozoal motility was obtained with the concentration of $1 \%$ with respect to the control. Alive sperm\%, abnormalities\%, and \% of intact spermatozoa membranes (HOST\%) were similar to the control with all concentrations of kaki used. The conception rate was higher when 1-6\% KEE were used.

Conclusions: Some concentrations of Diospyros kaki improved buffalo bull semen quality post-chilling, post-freezing, the conception rate, and the concentration $1 \%$ gave the best results.
\end{abstract}

Keywords: Buffalo, Semen, Preservation, Diospyros kaki

\section{Background}

Sperm cryopreservation and storage are of a great need for maintaining the supergenetic characters of the males and the implementation of artificial reproductive applications as artificial insemination (AI) and in vitro fertilization (IVF) (Medeiros et al. 2002). AI with frozen semen is of a great value for selection schedules participating in increased production of animal species. Semen freezing has many beneficial applications. Several factors (storage temperature, cooling rate, chemical ingredients

\footnotetext{
*Correspondence: elnattat@gmail.com

Animal Reproduction and Al Department, Veterinary Research Division, National Research Centre, Dokki, Egypt
}

of the extender, cryopreservative percent, levels of oxygen free radicals, seminal plasma ingredients, and sanitary control) hindered the livability of spermatozoa (Barbas and Mascarenhas 2009). Freezing of buffalo sperm is often accompanied with the over accumulation of free radicals attended with a deficient antioxidant enzymatic system within the sperm which increased the liability of the sperm membrane to oxidative deterioration (El-Sisy et al. 2007) that affect the membrane integrity (Awda et al. 2009). Nowadays, the application of phytochemicals has gained interest among the world population. The fruit antioxidants induced a defensive system that maintains the metabolism and viability of frozen 
bovine spermatozoa (Câmara et al. 2011). Persimmon (Diospyros kaki) fruit was one of those plants having high nutritive value and inclosed many biologically active substances including antioxidants, triterpenoids, fiber, and minerals (Gorinstein et al., 2001; Chen et al. 2008; Park et al. 2008; Akter and Eun 2009; Veberic et al. 2010; Zhou et al. 2010; Dembitsky et al. 2011). It had multiple medicinal values, according to the variety of antioxidants involving phenolics, carotenoids, and vitamin C (George and Redpath 2008). Persimmon contained different types of nutritive materials such as polyphenols, organic acid, carbohydrates vitamins, tannins, dietary fiber, carotenoids, and triterpenoids that affected significantly their nutritive and medicinal values (Matsuo and Ito 1978; Ebert and Gross 1985; Gorinstein 1999; Liu and Xie 2001; Ma et al. 2005; Yuan et al. 2006; Celik and Ercisli 2007; Del Bubba et al. 2009). No available literature was found for interpreting the benefit for using those materials in preserving buffalo semen. So, the aim of the study is to clarify the impact of Diospyros kaki of preserved buffalo semen quality.

\section{Materials and methods}

Preparation of semen extender: kaki-enhanced extender [KEE]

Five milliliters of blended Persimmon (Diospyros kaki) flesh was supplemented to $45 \mathrm{ml}$ tris-citrate-fructose (TCF) to obtain $10 \%$ stock solution. KEE was set by supplementing variable concentrations $0.0 \mathrm{ml} / 5.0 \mathrm{ml}$ (control, 0\%), $0.5 \mathrm{ml} / 4.5 \mathrm{ml}$ (1\%), $1 \mathrm{ml} / 4 \mathrm{ml}$ (2\%), 1.5 $\mathrm{ml} / 3.5 \mathrm{ml} \mathrm{(3 \% ),} 2.0 \mathrm{ml} / 3.0 \mathrm{ml}$ (4\%), $2.5 \mathrm{ml} / 2.5 \mathrm{ml} \mathrm{(5 \% )}$, $3.0 \mathrm{ml} / 2.0 \mathrm{ml} \quad(6 \%), \quad 3.5 \mathrm{ml} / 1.5 \mathrm{ml} \quad(7 \%), \quad 4.0 \mathrm{ml} / 1.0 \mathrm{ml}$ (8\%), $4.5 \mathrm{ml} / 0.5 \mathrm{ml}(9 \%)$, and $5.0 \mathrm{ml} / 0.0 \mathrm{ml}(10 \%)$ to TCF to obtain a final volume of $5 \mathrm{ml}$. Twenty percent of whole egg yolk was enclosed in each tube to get KEE with $20 \%$ egg yolk (KEEY), all tubes were centrifuged to eliminate the debris. Supernatants were got into other tubes and then stored at $-20^{\circ} \mathrm{C}$ till used. A preliminary study on the employ of 10 to $50 \%$ had given bad results, so the former concentrations were introduced as the persimmon contained high amount of astringent tannin (Akagi et al. 2010) which might be the cause of those poor results

\section{Semen collection and primary assessment}

Semen was collected from three mature buffalo bulls kept at Semen Freezing Center, General Organization for Veterinary Services Ministry of Agriculture, Abbasia, Egypt. Ejaculates were collected using an artificial vagina at weekly intervals for 4.5 months. Collected semen was assessed for forward sperm motility and sperm concentration. Ejaculates fulfilling forward sperm motility (70\%) were used and pooled to get enough semen for a replicate and to avoid the individual bull variation. Semen was kept for $10 \mathrm{~min}$ at $37^{\circ} \mathrm{C}$ in the water bath before the extension.

\section{Semen processing}

Collected semen was extended with TCF extender and kept as a control and other portions of pooled semen were extended with TCF extenders containing the different concentrations of kaki to achieve a concentration of 60 million sperm $/ \mathrm{ml}$. Diluted semen was refrigerated slowly (approximately for $2 \mathrm{~h}$ ) to $5{ }^{\circ} \mathrm{C}$ and equilibrated for $2 \mathrm{~h}$. Semen was filled into a $0.25 \mathrm{ml}$ polyvinyl French straws. After equilibrium periods, the straws were horizontally placed on a rack and exposed to vapor $4 \mathrm{~cm}$ above liquid nitrogen for $10 \mathrm{~min}$ and were then plunged in liquid nitrogen. A portion of extended semen from control and each concentration of the additives were refrigerated at $5{ }^{\circ} \mathrm{C}$ for 7-10 days (chilling) and sperm forward motility was daily assessed.

\section{Assessment of semen quality parameters}

The evaluation was implemented on after freeze-thawed buffalo bull spermatozoa. Also, sperm forward motility was evaluated for raw semen, $2 \mathrm{~h}$ post cooling and chilled semen daily up to 7-10 days. Frozen straws were thawed at $37^{\circ} \mathrm{C}$ for $1 \mathrm{~min}$. The parameters done were motility, alive, abnormality, and sperm membrane integrity (HOST) \% (Salisbury et al. 1978).

\section{In vivo fertility rate (CR)}

One hundred and forty-five buffalo cows were inseminated with straws representing the different concentrations of KEEY post-thawed semen (one straw for each buffalo in estrus). Each straw contained $15 \times 10^{6}$ forward motile sperm necessary for a desirable fertility level (Mohanty et al. 2018). Ten buffalo cows were inseminated with the post-thawed semen extended in TCFY (control group). Pregnancy was detected by rectal palpation after 2 months from insemination (non-return rate). The inseminated buffalo cows were used via the cooperation in Beni-Suef Governorate. CR was computed according to the equation:

$$
\mathrm{CR}=\frac{\text { no.of conceived cows }}{\text { total no.of inseminated cows }} \times 100
$$

\section{Statistical analysis}

Statistical analysis data were computed with SPSS (2005) computerized program v. 14.0 to calculate the one-way analysis of variance (ANOVA) for the different parameters between control and the different concentrations within column either for the cooling in each day (without considering the time factor) or for the after freeze-thawing procedures. Significant difference among means was calculated using Duncan multiple range test at $P<0.05$. 


\section{Results}

Effect of tris extender enhanced with Diospyros kaki on forward sperm motility of chilled buffalo bull semen Concerning the time effect on sperm motility, the sperm motility gradually and normally decline with the progress of time $(P<0.0001)$ (Table 1$)$.

Sperm forward motility was significantly $(P<0.0001)$ kept high after chilling for 5 days with the concentrations 3 , 4, and $5 \%$ (41.67 $\pm 1.67,41.67 \pm 1.67$, and $41.67 \pm 1.67$, respectively) when compared to the control $(20.00 \pm 2.89)$ and also significantly $(P<0.01)$ kept high at the other concentrations till 4 days of chilling (Table 1 ).

\section{Effect of tris extender enhanced with Diospyros kaki on sperm criteria of frozen buffalo bull semen}

Addition of KEE had significantly $(P<0.03)$ improved post thawing sperm motility\% with all the concentrations except the concentrations $10 \%$ the highest sperm forward motility was obtained with the concentration $1 \%$ $(50.00 \pm 5.77 \%)$ (Table 2).
Effect of tris extender enhanced with Diospyros kaki on conception rate of frozen buffalo bull semen

Conception rate was higher in buffalo with concentrations $1-6 \%$ kaki $(66.6 \%, 50.0 \%, 50.0 \%, 50.0 \%, 52.9 \%$, and $57.14 \%$ ) (Table 3).

\section{Discussion}

Semen freezing protocol was a vital request (Medeiros et al. 2002). Cryopreservation caused wide-ranging chemical, physical, and mechanical injures to sperm membranes of all mammalian species (Watson 2000), which were related to changes in temperature and in the conversion from the lipid phase, production of oxygen free radicals and osmotic stress (Câmara et al. 2011; Ortega Ferrusola et al. 2009). Moreover, the excessive ROS caused a state of oxidative damage that involved structural damage of sperm membranes, fall of intracellular ATP levels causing a decrease in the vitality of frozen sperms (Baumber et al. 2000; Agarwal et al. 2005). To alleviate the hazardous effects of ROS, seminal

Table 1 Effect of Diospyros kaki-enhanced extender on buffalo bull sperm motility during chilling

\begin{tabular}{|c|c|c|c|c|c|c|c|c|c|c|}
\hline \multirow[t]{2}{*}{ Treatment } & \multirow[t]{2}{*}{ Time (2 h) } & \multicolumn{7}{|l|}{ Days } & \multirow{2}{*}{$\begin{array}{l}F \\
\text { value }\end{array}$} & \multirow[t]{2}{*}{$\mathrm{P}<$} \\
\hline & & 1 & 2 & 3 & 4 & 5 & 6 & 7 & & \\
\hline Control & $\begin{array}{l}90.00^{\mathrm{aA}} \pm \\
0.00\end{array}$ & $\begin{array}{l}80.00^{\mathrm{bAB}} \pm \\
0.00\end{array}$ & $\begin{array}{l}73.33^{\mathrm{cdBC}} \pm \\
3.33\end{array}$ & $\begin{array}{l}60.00^{\mathrm{dC}} \pm \\
5.77\end{array}$ & $\begin{array}{l}45.00^{\mathrm{CD}} \pm \\
10.41\end{array}$ & $20.00^{\mathrm{dE}} \pm 2.89$ & $1.67^{\mathrm{cF}} \pm 1.67$ & $\begin{array}{l}0.00^{\mathrm{CF}} \pm \\
0.00^{-}\end{array}$ & 61.32 & 0.0001 \\
\hline $1 \%$ & $\begin{array}{l}90.00^{\mathrm{aA}} \pm \\
0.00\end{array}$ & $\begin{array}{l}80.00^{\mathrm{bB}} \pm \\
0.00\end{array}$ & $70.00^{d C} \pm 0.00$ & $\begin{array}{l}68.33^{\mathrm{bcc}} \pm \\
1.67\end{array}$ & $\begin{array}{l}56.67^{\mathrm{abcD}} \pm \\
1.67\end{array}$ & $\begin{array}{l}33.33^{\mathrm{abE}} \pm \\
1.67\end{array}$ & $\begin{array}{l}8.33^{\mathrm{bcF}} \pm \\
1.67\end{array}$ & $\begin{array}{l}0.00^{\mathrm{cG}} \pm \\
0.00^{-1}\end{array}$ & 383.64 & 0.0001 \\
\hline $2 \%$ & $\begin{array}{l}90.00^{\mathrm{aA}} \pm \\
0.00\end{array}$ & $\begin{array}{l}85.00^{\mathrm{aA}} \pm \\
0.00\end{array}$ & $70.00^{\mathrm{dB}} \pm 0.00$ & $\begin{array}{l}66.67^{\mathrm{cdB}} \pm \\
3.33\end{array}$ & $\begin{array}{l}55.00^{\mathrm{abcc}} \pm \\
2.89\end{array}$ & $\begin{array}{l}30.00^{\mathrm{bcD}} \pm \\
2.89\end{array}$ & $\begin{array}{l}8.33^{\mathrm{bcE}} \pm \\
1.67\end{array}$ & $\begin{array}{l}0.00^{\mathrm{CE}} \pm \\
0.00\end{array}$ & 243.38 & 0.0001 \\
\hline $3 \%$ & $\begin{array}{l}91.67^{\mathrm{aA}} \pm \\
1.67\end{array}$ & $\begin{array}{l}85.00^{\mathrm{aB}} \pm \\
0.00\end{array}$ & $\begin{array}{l}81.67^{\mathrm{abBC}} \pm \\
1.67\end{array}$ & $78.33^{\mathrm{ac}} \pm 1.67$ & $66.67^{\mathrm{aD}} \pm 1.67$ & $41.67^{\mathrm{aE}} \pm 1.67$ & $\begin{array}{l}23.33^{\mathrm{aF}} \pm \\
1.67\end{array}$ & $\begin{array}{l}6.67^{\mathrm{abG}} \pm \\
3.33\end{array}$ & 492.19 & 0.0001 \\
\hline $4 \%$ & $\begin{array}{l}88.33^{\mathrm{aA}} \pm \\
1.67\end{array}$ & $\begin{array}{l}85.00^{\mathrm{aAB}} \pm \\
0.00\end{array}$ & $\begin{array}{l}81.67^{\mathrm{abB}} \pm \\
1.67\end{array}$ & $\begin{array}{l}76.67^{\mathrm{abc}} \pm \\
1.67\end{array}$ & $63.33^{\mathrm{aD}} \pm 1.67$ & $41.67^{\mathrm{aE}} \pm 1.67$ & $\begin{array}{l}25.00^{\mathrm{aF}} \pm \\
2.89\end{array}$ & $\begin{array}{l}10.00^{\mathrm{aG}} \pm \\
2.89\end{array}$ & 375.70 & 0.0001 \\
\hline $5 \%$ & $\begin{array}{l}90.00^{\mathrm{aA}} \pm \\
2.89\end{array}$ & $\begin{array}{l}85.00^{\mathrm{aB}} \pm \\
0.00\end{array}$ & $\begin{array}{l}81.67^{\mathrm{abB}} \pm \\
1.67\end{array}$ & $\begin{array}{l}76.67^{\mathrm{abc}} \pm \\
1.67\end{array}$ & $63.33^{\mathrm{aD}} \pm 1.67$ & $41.67^{\mathrm{aE}} \pm 1.67$ & $\begin{array}{l}20.00^{\mathrm{aF}} \pm \\
0.00\end{array}$ & $\begin{array}{l}3.33^{\mathrm{bcG}} \pm \\
1.67\end{array}$ & 456.14 & 0.0001 \\
\hline $6 \%$ & $\begin{array}{l}88.33^{\mathrm{aA}} \pm \\
1.67\end{array}$ & $\begin{array}{l}85.00^{\mathrm{aA}} \pm \\
0.00\end{array}$ & $\begin{array}{l}81.67^{\mathrm{abAB}} \pm \\
1.67\end{array}$ & $\begin{array}{l}76.67^{\mathrm{abB}} \pm \\
1.67\end{array}$ & $\begin{array}{l}55.00^{\mathrm{abcc}} \pm \\
2.89\end{array}$ & $\begin{array}{l}30.00^{\mathrm{bcD}} \pm \\
2.89\end{array}$ & $\begin{array}{l}11.67^{\mathrm{bE}} \pm \\
3.33\end{array}$ & $\begin{array}{l}0.00^{\mathrm{CF}} \pm \\
0.00\end{array}$ & 275.42 & 0.0001 \\
\hline $7 \%$ & $\begin{array}{l}88.33^{\mathrm{aA}} \pm \\
1.67\end{array}$ & $\begin{array}{l}85.00^{\mathrm{aA}} \pm \\
0.00\end{array}$ & $85.00^{\mathrm{aA}} \pm 0.00$ & $81.67^{\mathrm{aA}} \pm 1.67$ & $\begin{array}{l}60.00^{\mathrm{abB}} \pm \\
2.89\end{array}$ & $\begin{array}{l}33.33^{\mathrm{abc}} \pm \\
4.41\end{array}$ & $\begin{array}{l}10.00^{\mathrm{bD}} \pm \\
2.89\end{array}$ & $\begin{array}{l}0.00^{\mathrm{CE}} \pm \\
0.00\end{array}$ & 251.39 & 0.0001 \\
\hline $8 \%$ & $\begin{array}{l}88.33^{\mathrm{aA}} \pm \\
1.67\end{array}$ & $\begin{array}{l}85.00^{\mathrm{aA}} \pm \\
0.00\end{array}$ & $\begin{array}{l}76.67^{\mathrm{bcB}} \pm \\
1.67\end{array}$ & $\begin{array}{l}73.33^{\mathrm{abcB}} \pm \\
1.67\end{array}$ & $\begin{array}{l}48.33^{\mathrm{bcc}} \pm \\
1.67\end{array}$ & $\begin{array}{l}25.00^{\mathrm{bcdD}} \pm \\
2.89\end{array}$ & $\begin{array}{l}10.00^{\mathrm{bE}} \pm \\
2.89\end{array}$ & $\begin{array}{l}0.00^{\mathrm{CF}} \pm \\
0.00\end{array}$ & 356.80 & 0.0001 \\
\hline $9 \%$ & $\begin{array}{l}88.33^{\mathrm{aA}} \pm \\
1.67\end{array}$ & $\begin{array}{l}85.00^{\mathrm{aAB}} \pm \\
0.00\end{array}$ & $\begin{array}{l}80.00^{\mathrm{abB}} \pm \\
0.00\end{array}$ & $\begin{array}{l}73.33^{\mathrm{abcc}} \pm \\
1.67\end{array}$ & $\begin{array}{l}48.33^{\mathrm{bcD}} \pm \\
1.67\end{array}$ & $\begin{array}{l}23.33^{\mathrm{cdE}} \pm \\
1.67\end{array}$ & $\begin{array}{l}6.67^{\mathrm{bcF}} \\
\pm 1.67\end{array}$ & $\begin{array}{l}0.00^{\mathrm{CF}} \pm \\
0.00\end{array}$ & 386.03 & 0.0001 \\
\hline $10 \%$ & $\begin{array}{l}88.33^{\mathrm{aA}} \pm \\
1.67\end{array}$ & $\begin{array}{l}85.00^{\mathrm{aAB}} \pm \\
0.00\end{array}$ & $\begin{array}{l}80.00^{\mathrm{abBC}} \pm \\
0.00\end{array}$ & $\begin{array}{l}73.33^{\mathrm{abcc}} \pm \\
1.67\end{array}$ & $\begin{array}{l}55.00^{\mathrm{abcD}} \pm \\
5.00\end{array}$ & $\begin{array}{l}25.00^{\mathrm{bcdE}} \pm \\
2.89\end{array}$ & $\begin{array}{l}8.33^{\mathrm{bcF}} \pm \\
3.33\end{array}$ & $\begin{array}{l}0.00^{\mathrm{cG}} \pm \\
0.00^{-}\end{array}$ & 205.64 & 0.0001 \\
\hline$F$ value & 0.52 & Infty & 11.49 & 5.94 & 3.01 & 8.87 & 9.81 & 5.90 & & \\
\hline$P<$ & 0.8578 & 0.0001 & 0.0001 & 0.0002 & 0.0149 & 0.0001 & 0.0001 & 0.0003 & & \\
\hline
\end{tabular}

Mean \pm S.E.

Different small letter superscripts indicate a significant difference between means within column (for treatment) using the multiple range Duncan's test at $P$ $<0.05$

Different capital letter superscripts indicate a significant difference between means within row (for time) using the multiple range Duncan's test at $P<0.05$ 
Table 2 Effect of Diospyros kaki-enhanced extender on post thawing buffalo bull sperm characteristics

\begin{tabular}{lllll}
\hline \multirow{2}{*}{ Treatment } & Parameter & & & \\
\cline { 2 - 5 } & Motile $\%$ & HOST $\%$ & Alive $\%$ & Abnormality $\%$ \\
\hline Control & $26.67^{\mathrm{b}} \pm 3.33$ & $73.33^{\mathrm{a}} \pm 8.25$ & $80.00^{\mathrm{a}} \pm 1.73$ & $18.67^{\mathrm{a}} \pm 2.40$ \\
$1 \%$ & $50.00^{\mathrm{a}} \pm 5.77$ & $83.00^{\mathrm{a}} \pm 1.15$ & $78.33^{\mathrm{a}} \pm 1.33$ & $22.67^{\mathrm{a}} \pm 2.19$ \\
$2 \%$ & $43.33^{\mathrm{a}} \pm 6.67$ & $78.00^{\mathrm{a}} \pm 1.53$ & $74.00^{\mathrm{a}} \pm 2.52$ & $23.67^{\mathrm{a}} \pm 2.33$ \\
$3 \%$ & $45.00^{\mathrm{a}} \pm 5.00$ & $79.67^{\mathrm{a}} \pm 0.88$ & $81.00^{\mathrm{a}} \pm 0.58$ & $23.00^{\mathrm{a}} \pm 4.73$ \\
$4 \%$ & $40.00^{\mathrm{ab}} \pm 0.00$ & $84.67^{\mathrm{a}} \pm 0.88$ & $84.00^{\mathrm{a}} \pm 4.93$ & $22.33^{\mathrm{a}} \pm 6.84$ \\
$5 \%$ & $46.67^{\mathrm{a}} \pm 8.82$ & $78.67^{\mathrm{a}} \pm 1.86$ & $79.00^{\mathrm{a}} \pm 1.00$ & $21.33^{\mathrm{a}} \pm 5.36$ \\
$6 \%$ & $41.67^{\mathrm{ab}} \pm 1.67$ & $84.67^{\mathrm{a}} \pm 3.18$ & $80.33^{\mathrm{a}} \pm 5.46$ & $17.67^{\mathrm{a}} \pm 3.18$ \\
$7 \%$ & $41.67^{\mathrm{ab}} \pm 1.67$ & $74.67^{\mathrm{a}} \pm 0.88$ & $74.33^{\mathrm{a}} \pm 1.76$ & $22.00^{\mathrm{a}} \pm 2.52$ \\
$8 \%$ & $40.00^{\mathrm{ab}} \pm 5.00$ & $79.67^{\mathrm{a}} \pm 0.88$ & $70.67^{\mathrm{a}} \pm 1.76$ & $25.67^{\mathrm{a}} \pm 4.26$ \\
$9 \%$ & $36.67^{\mathrm{ab}} \pm 3.33$ & $81.00^{\mathrm{a}} \pm 1.00$ & $71.33^{\mathrm{a}} \pm 2.96$ & $24.00^{\mathrm{a}} \pm 3.06$ \\
$10 \%$ & $26.67^{\mathrm{b}} \pm 3.33$ & $78.00^{\mathrm{a}} \pm 3.06$ & $79.00^{\mathrm{a}} \pm 4.93$ & $21.33^{\mathrm{a}} \pm 6.33$ \\
F value & 2.49 & 1.50 & 1.88 & 0.29 \\
$P<$ & 0.0360 & 0.2059 & 0.1045 & 0.9759 \\
\hline
\end{tabular}

Mean \pm S.E.

Different letter superscripts indicate a significant difference between means within column using the multiple range Duncan's test at $P<0.05$

plasma had a potent source of oxygen free radicals, scavengers that offered protection for sperm, including superoxide dismutase, glutathione peroxidase, catalase enzymes, vit. $C$, and $\alpha$-tocopherol (Aitken and Baker 2004; Sikka 2004). Including cryoprotectants in the semen diluent during refrigeration, freeze-thawing of sperm cells reduced the spermatozoal damage and consequently improved livability and consequent fertilizing capacity (Gadea et al. 2007; Uysal and Bucak 2007; Bucak et al. 2008). The natural additives contained antioxidants to antagonize the hazardous action of the oxygen-free radicals. Concerning the buffalo semen, semen was chilled to ensure till which day of chilling it

Table 3 Effect of Diospyros kaki enriched extender on a field conception rate test in buffalo

\begin{tabular}{ll}
\hline Treatment & In vivo fertility rate $(\mathrm{CR}, \%)$ \\
\hline Control & 45.50 \\
KEE 1\% & $66.6 \%$ \\
KEE 2\% & $50 \%$ \\
KEE 3\% & $50 \%$ \\
KEE 4\% & $50 \%$ \\
KEE 5\% & $52.9 \%$ \\
KEE 6\% & $57.14 \%$ \\
KEE 7\% & $33.33 \%$ \\
KEE 8\% & $33.33 \%$ \\
KEE 9\% & $25 \%$ \\
KEE 10\% & $50.00 \%$ \\
\hline
\end{tabular}

could be used in artificial insemination where the sperm motility must not be less than $50 \%$. The decline of sperm motility in chilled semen in all concentrations of kaki extract as well as in the control was used as a good indicator to inform us on which day we do not use it in in vivo fertility. Sperm forward motility was kept high after chilling for 5 days at the concentrations 3, 4, and $5 \%$ KEEY while it was kept high up to chilling for 4 days for the other concentrations. Conversely, KEEY had improved the post freezing spermatozoal motility with all concentrations (1-9\%) except the 10\%. Higher conception rate in buffalo with concentrations 1-6\% kaki coincided with the good post-thawing sperm parameters with these concentrations. The used concentrations (1$10 \%$ ) had maintained alive $\%$, abnormalities $\%$, and \% of intact spermatozoal membranes (HOST\%). Freezing of buffalo semen exerted an additional source of reactive oxygen (ROS) attack and lipid peroxidation (El-Sisy et al. 2007) which affected the membrane permeability (Awda et al. 2009). The increased ROS level was attributed to the reduced levels of antioxidant enzymes. Natural antioxidants maintained the metabolism and livability of frozen buffalo spermatozoa (Câmara et al. 2011).

Diospyros kaki contained potent antioxidant ingredients as represented by high levels of carotenoids (Zhou et al. 2010; Zaghdoudi et al. 2015), flavonoids, and polyphenols (Denev et al. 2013; Sun et al. 2014; Xie et al. 2015), organic acids, and vitamins (Zhou et al. 2010; Karakasova et al. 2013), minerals (Marqués et al. 2015), and carbohydrates (Baltacioglu and Artik 2013; Zhou et al. 2010). Olayemi et al. (2011) and Aljady et al. (2000) recorded that flavonoids and phenolics compounds had efficient antioxidant potential and superior viability of preserved spermatozoa. Flavonoids and phenolics were strong eliminators of the oxygen free radicals and the number of hydroxyl group on the phenyl ring improved the antioxidant capability of polyphenolic molecule (Wettasinghe and Shahidi 2000; LeBlanc et al. 2009). Kaki contained large amounts of flavonoids that possessed high antioxidant capacity and decreased the release of nitric oxide and malondialdehyde and minimized the apoptotic damage (Sun et al. 2014). Flavonoids, vitamins, and organic acids found in pollen grains and honey are antioxidants that improve the preservability of bull semen (El-Sheshtawy et al. 2014a, b).

\section{Conclusion}

It could be concluded that some concentrations of Diospyros kaki improved buffalo bull semen quality postchilling and post-freezing, also upregulated the conception rate and the concentration $1 \%$ gave the best results.

\section{Abbreviations}

KEE: Kaki-enhanced extender; KEEY: Kaki-enhanced extender egg yolk; HOST: Hypo-osmotic swelling test/sperm membrane integrity test; 
Al: Artificial insemination; IVF: In vitro fertilization; TCF: Tris citrate fructose extender; TCFY: Tris citrate fructose egg yolk extender; CR: Conception rate; ANOVA: Analysis of variance

\section{Acknowledgements}

The authors give special thanks to all the lab and co-workers in the Department of Animal Reproduction and Al (National Research Centre), as well as to the co-workers in the Artificial Insemination Centre (Ministry of Agriculture and Land Reclamation, Egypt) for their help and support in this study.

\section{Consent of publication}

Not applicable.

\section{Authors' contributions}

Both authors RES and WEN had shared all the items of the experimental design, the collection of semen, the extraction, the diluting concentrations, the preparation of the manuscript, and Dr. WEN had performed the statistical analysis and tabulation.

\section{Funding}

The present work is financially supported by the National Research Centre, Egypt [grant numbers: 10120801].

\section{Availability of data and materials}

The authors claimed the availability of data and materials.

\section{Ethics approval and consent to participate}

The experimental design on buffalo bulls and their ejaculates has been approved by the Medical Research Ethics Committee at the National Research Centre, Egypt under the license no. 17/155.

\section{Competing interests}

The authors declare that they have no competing interests.

Received: 22 January 2020 Accepted: 4 June 2020

Published online: 15 June 2020

\section{References}

Agarwal A, Prahakaran SA, Said TM (2005) Prevention of oxidative stress injury to sperm. J. Androl. 26:653-660

Aitken RJ, Baker MA (2004) Oxidative stress and male reproductive biology. Reprod. Fertil. Dev. 16(5):581-588

Akagi T, Suzuki Y, Ikegami A, Kamitakahara H, Takano T, Nakatsubo F et al (2010) Condensed tannin composition analysis in persimmon (Diospyros kaki Thunb. ) fruit by acid catalysis in the presence of excess phloroglucinol. J. Japan Soc. Hort. Sci. 79(3):275-281

Akter MS, Eun JB. Characterization of insoluble fibers prepared from the peel of ripe soft persimmon (Diospyros kaki L. cv. Daebong). Food Sci. Biotechnol. 2009; 18:1545-1547

Aljady AM, Kamaruddin MY, Jamal AM, Mohd Yassin MY (2000) Biochemical study on the efficacy of Malaysian honey in infected wounds: an animal model. Med. J. Islam Acad. Sci. 13(3):125-132

Awda BJ, Mackenzie-Bell M, Buhr MM (2009) Reactive oxygen species and boar sperm function. Biol. Reprod. 81(3):553-561

Baltacioglu H, Artik N (2013) Study of postharvest changes in the chemical composition of persimmon by HPLC. Turk. J. Agric. For. 37:568-574

Barbas JP, Mascarenhas RD (2009) Cryopreservation of domestic animal sperm cells. Cell Tissue Bank 10:49-62

Baumber J, Ball BA, Gravence CG, Medina V, Davies-Morel MC (2000) The effect of reactive oxygen species on equine sperm motility, viability, acrosomal integrity, mitochondrial membrane potential, and membrane lipid peroxidation. J. Androl. 21(6):895-902

Bucak MN, Atessahin A, Yuce A (2008) Effect of anti-oxidants and oxidative stress parameters on ram semen after the freeze-thawing process. Small Rum. Res. 75:128-134

Câmara DR, Mello-Pinto MMC, Pinto IC, Brasil OO, Nunes JF, Guerr MMP (2011) Effects of reduced glutathione and catalase on the kinematics and membrane functionality of sperm during liquid storage of ram semen. Small Rumin. Res. 100:44-49

Celik A, Ercisli S (2007) Persimmon cv. Hachiya (Diospyros kaki Thunb.) fruit: some physical, chemical and nutritional properties. Int. J. Food Sci. Nutr. 18:1-8
Chen XN, Fan JF, Yue X, Wu XR, Li LT (2008) Radical scavenging activity and phenolic compounds in persimmon (Diospyros kaki L. cv. Mopan). J. Food Sci. 73:C24-C28

Del Bubba M, Giordani E, Pippucci L, Cincinelli A, Checchini L, Galvan P (2009) Changes in tannins, ascorbic acid and sugar contents in astringent persimmons during on-tree growth and ripening and in response to different postharvest treatments. J. Food Compos. Anal. 22:668-677

Dembitsky VM, Poovarodom S, Leontowicz H, Leontowicz M, Trakhtenberg S, Gorinstein S et al (2011) The multiple nutrition properties of some exotic fruits: biological activity and active metabolites. Food Res. Int. 144:1671-1701

Denev P, Yordanov A (2013) Total polyphenol, proanthocyanidin and flavonoid content, carbohydrate composition and antioxidant activity of persimmon (Diospyros kaki L.) fruit in relation to cultivar and maturity stage. Bulg. J. Agric. Sci. 19(5):981-988

Ebert G, Gross J (1985) Carotenoid changes in the peel of ripening persimmon (Diospyros kaki) cv. Triumph. Phytochemistry 24:29-32

El-Sheshtawy RI, El-Nattat WS, Ali AH, Sabra HA (2014a) The effect of Phoenix dactylifera pollen grains tris-infusion on semen preservability of local bull breeds. Global Vet. 13(5):728-732

El-Sheshtawy RI, El-Nattat WS, Sabra HA, Ali AH (2014b) Effect of honey solution on semen preservability of local breeds of cattle bulls. Wrld. Appl. Sci. J. 32(10):2076-2078

El-Sisy GA, El-Nattat WS, El-Sheshtawy RI (2007) Buffalo semen quality, antioxidants and peroxidation during chilling and cryopreservation. Online J. Vet. Res. 11:55-61

Gadea J, Gumbao D, Cánovas S, García-Vázquez FA, Grullón LA, Gardón JC (2007) Supplementation of the dilution medium after thawing with reduced glutathione improves function and the in vitro fertilizing ability of frozenthawed bull spermatozoa. Int J Androl. 31:40-49

George AP, Redpath S (2008) Health and medicinal benefits of persimmon fruit: a review. Adv. Hort. Sci. 22:244-249

Gorinstein S (1999) Comparative content of total polyphenols and dietary fiber in tropical fruits and persimmon. J. Nutr. Biochem. 10:367-371

Gorinstein S, Zemser M, Zachwieja Z, Weisz M, Folta M, Barton H et al (2001) Comparative contents of dietary fiber, total phenolics, and minerals in persimmons and apples. J. Agric. Food Chem. 49:952-957

Karakasova L, Babanovska-Milenkovska F, Lazov M, Karakasov B, Stojanova M (2013) Quality properties of solar dried persimmon (Diospyros kaki). J. Hyg. Eng. Design. 4:54-59

LeBlanc BW, Davis OK, Boue S, DeLucca A, Deeby T (2009) Antioxidant activity of Sonoran desert bee pollen. Food Chem. 115:1299-1305

Liu YJ, Xie JL (2001) Ursolate compounds from fruit of Diospyros kaki L. f. (in (hinese). J. Plant Resour. Environ. 10:1-3

Ma Q, Qin T, Zhang Q (2005) Analysis of ingredient in persimmon frost (in Chinese). Food Res. Dev. 26:143-145

Marqués AM, Domingo A, Cervera ML, de la Guardia M (2015) Mineral profile of kaki fruits (Diospyros kaki L.). Food Chem. 172:291-297

Matsuo T, Ito S (1978) The chemical structure of kaki-tannin from immature fruit of the persimmon (Diospyros kaki L.) (in Japanese). Agr. Biol. Chem. 42:1637-1643

Medeiros CM, Forell F, Oliveira AT, Rodrigues JL (2002) Current status of sperm cryopreservation: why isn't better. Theriogenology 57:327-344

Mohanty TK, Lone SA, Kumaresan A, Bhakat M, Kumar R, Baithalu RK et al (2018) Sperm dosage and site of insemination in relation to fertility in bovines. Asian Pacific J. Reprod. 7(1):1-5

Olayemi F, Adedayo R, Muhummad R, Bamishaiye E (2011) The nutritional quality of three varieties of zobo (Hibiscus sabadariffa) subjected to the same preparation condition. Plant Food Hum. Nutr. 6:10-15

Ortega Ferrusola C, González Fernández L, Morrell JM, Salazar Sandoval C, Macías García B, Rodríguez-Martinez H, Tapia JA, Peña FJ (2009) Lipid peroxidation, assessed with BODIPY-C11, increases after cryopreservation of stallion spermatozoa, is stallion dependent and is related to apoptotic-like changes. Reproduction 138(1):55-63

Park YS, Leontowicz H, Leontowicz M, Namiesnik J, Jesion I, Gorinstein S (2008) Nutraceutical value of persimmon (Diospyros kaki Thunb.) and its influence on some indices of atherosclerosis in an experiment on rats fed cholesterol containing diet. Adv. Hort. Sci. 22(4):250-254

Salisbury GW, Van Demark NL, Lodge JR. Semen evaluation, pp. 400-427 In: Physiology of reproduction and artificial insemination of cattle, 2nd edition, W.H. Freeman \& Compagny, San Francisco, USA, 1978.

Sikka SC (2004) Role of oxidative stress and antioxidants in andrology and assisted reproductive technology. J. Androl. 25(1):5-18 
SPSS. SPSS v.14.0 for Windows Evaluation Version Release. 14.0.0., 2005.

Sun L, Zhang J, Fang K, Ding Y, Zhang L, Zhang Y (2014) Flavonoids from persimmon (Diospyros kaki) leaves (FPL) attenuate H2O2-induced apoptosis in MC3T3-E1 cells via the NF-[small kappa]B-pathway. Food Funct. 5:471-479

Uysal O, Bucak MN. Effects of oxidized glutathione, bovine serum albumin,cysteine and lycopene on the quality of frozen-thawed ram semen. Acta Vet. Brno. 2007; 76:383-390

Veberic R, Jurhar J, Mikulic-Petkovsek M, Stampar F, Schmitzer V (2010) Comparative study of primary and secondary metabolites in 11 cultivars of persimmon fruit (Diospyros kaki L.). Food Chem. 119:477-483

Watson PF (2000) The causes of reduced fertility with cryopreserved semen. Anim. Reprod. Sci. 60-61:481-492

Wettasinghe M, Shahidi F (2000) Scavenging of reactive-oxygen species and DPPH free radicals by extracts of borage and evening primrose meals. Food Chem 70:17-26

Xie C, Xie Z, Xu X, Yang D (2015) Persimmon (Diospyros kaki L.) leaves: a review on traditional uses, phytochemistry and pharmacological properties. J. Ethnopharmacol. 163:229-240

Yuan B, Xu HL, Leng SP (2006) Content and chemical composition of carotenoids in persimmon fruit (in Chinese). Chin Agr. Sci. Bull. 22:277-280

Zaghdoudi K, Pontvianne S, Framboisier X, Achard M, Kudaibergenova R, Trabelsi MA, Cherif JK, Vanderesse R, Frochot C, Guiavarc'h Y (2015) Accelerated solvent extraction of carotenoids from: Tunisian kaki (Diospyros kaki L.), peach (Prunus persica L.) and apricot (Prunus armeniaca L.). Food Chem. 184:131-139

Zhou C, Sheng Y, Zhao D, Wang Z, Tao J (2010) Variation of oleanolic and ursolic acid in the flesh of persimmon fruit among different cultivars. Molecules 15 6580-6587

\section{Publisher's Note}

Springer Nature remains neutral with regard to jurisdictional claims in published maps and institutional affiliations.

\section{Submit your manuscript to a SpringerOpen ${ }^{\circ}$ journal and benefit from:}

- Convenient online submission

- Rigorous peer review

- Open access: articles freely available online

- High visibility within the field

- Retaining the copyright to your article

Submit your next manuscript at $\boldsymbol{\nabla}$ springeropen.com 